Systematic Review

Revisão Sistemática

Maysa Bastos Rabelo1 Ana Paula Corona ${ }^{2}$

Keywords

Systemic Scleroderma Hearing Loss

Vestibule Labyrinth Vertigo Review

Descritores

Escleroderma Sistêmico Perda Auditiva

Vestíbulo do Labirinto

Vertigem

Revisão

Correspondence address:

Maysa Bastos Rabelo

Departamento de Fonoaudiologia,

Instituto de Ciências da Saúde,

Universidade Federal da Bahia

Avenida Reitor Miguel Calmon, s/n,

$1^{\circ}$ andar, Vale do Canela, Salvador (BA),

Brasil, CEP: 40110-902.

E-mail: maysa_bastos@yahoo.com.br

Received: 05/05/2014

\section{Auditory and vestibular dysfunctions in systemic \\ sclerosis: literature review}

\section{Alterações auditivas e vestibulares na Esclerose Sistêmica: revisão de literatura}

\begin{abstract}
Purpose: To describe the prevalence of auditory and vestibular dysfunction in individuals with systemic sclerosis (SS) and the hypotheses to explain these changes. Research strategy: We performed a systematic review without meta-analysis from PubMed, LILACS, Web of Science, SciELO and SCOPUS databases, using a combination of keywords "systemic sclerosis AND balance OR vestibular" and "systemic sclerosis AND hearing OR auditory." Selection criteria: We included articles published in Portuguese, Spanish, or English until December 2011 and reviews, letters, and editorials were excluded. We found 254 articles, out of which 10 were selected. Data analysis: The study design was described, and the characteristics and frequency of the auditory and vestibular dysfunctions in these individuals were listed. Afterwards, we investigated the hypothesis built by the authors to explain the auditory and vestibular dysfunctions in SS. Results: Hearing loss was the most common finding, with prevalence ranging from 20 to $77 \%$, being bilateral sensorineural the most frequent type. It is hypothesized that the hearing impairment in SS is due to vascular changes in the cochlea. The prevalence of vestibular disorders ranged from 11 to $63 \%$, and the most frequent findings were changes in caloric testing, positional nystagmus, impaired oculocephalic response, changes in clinical tests of sensory interaction, and benign paroxysmal positional vertigo. Conclusion: High prevalence of auditory and vestibular dysfunctions in patients with SS was observed. Conducting further research can assist in early identification of these abnormalities, provide resources for professionals who work with these patients, and contribute to improving the quality of life of these individuals.
\end{abstract}

\section{RESUMO}

Objetivo: Descrever a prevalência das alterações auditivas e vestibulares em indivíduos com Esclerose Sistêmica (ES) e as hipóteses elencadas para explicar essas alterações. Estratégia de pesquisa: Revisão sistemática, sem meta-análise, a partir das bases de dados PubMed, LILACS, Isi Web of Science, SciELO e SCOPUS, utilizando a combinação das palavras-chave "systemic sclerosis AND balance OR vestibular" e "systemic sclerosis AND hearing OR auditory". Critérios de seleção: Foram incluídos artigos publicados em Português, Espanhol ou Inglês até dezembro de 2011 e excluídos os artigos de revisão de literatura, cartas e editoriais. Foram localizados 254 artigos e selecionados dez. Análise dos dados: Foi realizada a descrição do delineamento dos estudos e elencadas as características e frequência das alterações auditivas e vestibulares. Após, investigaram-se as hipóteses formuladas pelos autores para explicar o comprometimento auditivo e vestibular na ES. Resultados: A perda auditiva foi o achado mais comum, com prevalência de 20 a 77\%, sendo o tipo sensorioneural bilateral o mais frequente. Hipotetiza-se que o prejuízo auditivo na ES é decorrente de alterações vasculares na cóclea. A prevalência das alterações vestibulares variou de 11 a 63\%, e os achados mais frequentes foram alterações na prova calórica, nistagmo de posicionamento, resposta oculocefálica anormal, alterações nos testes clínicos de integração sensorial e vertigem postural paroxística benigna. Conclusão: Elevada prevalência de alterações auditivas e vestibulares em pacientes com ES. A condução de novas investigações pode colaborar na identificação precoce dessas alterações, fornecer subsídios para os profissionais que atuam junto a esses pacientes e contribuir para a melhoria da qualidade de vida desses indivíduos.

Study carried out at the Speech Language Pathology and Audiology Department, Universidade Federal da Bahia UFBA - Salvador (BA), Brazil.

(1) Graduate program in Interactive Processes of Organs and Systems, Universidade Federal da Bahia - UFBA Salvador (BA), Brazil.

(2) Speech Language Pathology and Audiology Department, Universidade Federal da Bahia - UFBA - Salvador (BA), Brazil.

Conflict of interests: nothing to declare. 


\section{INTRODUCTION}

Systemic sclerosis (SS), also known as systemic scleroderma, is an autoimmune connective tissue inflammatory disease, characterized by fibrosis of the skin, blood vessels, and visceral organs ${ }^{(1)}$. It is a rare disease affecting 4-12 individuals per 1,000,000 inhabitants/year. It is more common among persons aged between 30 and 50 years, and it is at least three times more frequent among women, especially those at fertile age ${ }^{(2,3)}$. The prevalence of the disease among women suggests the involvement of sex hormones on the development of SS. Despite being known since the 18th century, and even though it has been recognized as a multisystemic pathology since the 19th century, its etiology is unknown, and its pathogenesis is not clear ${ }^{(2)}$. Several chemical agents (vinyl chloride and benzene), drugs (bleomycin and toxic oil syndrome), or viral infections have been mentioned as the main precipitating factors for SS. The occurrence of the disease in other members of the family is rare ${ }^{(4)}$.

This condition is progressive and may cause death, being clinically characterized by skin thickening and problems in visceral organs, including the gastrointestinal tract, lungs, heart, and kidneys. Fibrosis and vascular occlusion occur in all the organs affected by SS. Because of vascular occlusion, the lumen of arteries and capillaries reduces and, as a consequence, isolated pulmonary hypertension takes place, as well as the reduction of capillary network (some vessels are obstructed and others are dilated, forming the telangiectasias), arterial hypertension due to the reduced renal artery lumen, myocardial perfusion disorder, and the Raynaud's phenomenon ${ }^{(4)}$.

Patients diagnosed with SS are classified in two subgroups, according to the extension of skin compromise ${ }^{(5)}$ : diffuse SS, in which skin, trunk and limbs, face, and neck are compromised; and limited SS, in which there are no trunk injuries, affecting only distal parts up to the knees and elbows, besides face and neck. The CREST syndrome (calcinosis, Raynaud's phenomenon, esophageal dysmotility, sclerodactyly, and telangiectasia) is one form of limited $\mathrm{SS}^{(4)}$.

In general, the disease has an insidious onset, and skin manifestations are followed or preceded by the Raynaud's phenomenon and edematous fingers ${ }^{(6,7)}$. Because multiple organs are affected, the disease can limit the relationships of the individuals and make social interactions more difficult, thus compromising the quality of life. A study conducted in 2012 reveals that $21-55 \%$ of the patients who have had the disease for approximately 10 years could not resume work due to their physical limitations ${ }^{(8)}$. Literature has also shown the presence of auditory and vestibular symptoms and changes in autoimmune diseases such as SS. However, studies that investigate these changes in SS are scarce, and the understanding of its physiopathology is still unclear. Considering that hearing enables interaction and social experiences, there is a need to investigate the integrity of this function, to intervene and minimize the losses resulting from auditory and vestibular changes, whenever possible. Besides, no publications on this subject were found in Brazil. The information about auditory and vestibular impairments in patients with SS can contribute to the knowledge of gaps about the problem, thus providing subsidies to professionals who work with these patients, improving quality of life of these patients.

\section{OBJECTIVE}

The objective of this study was to conduct a systematic literature review to describe and verify the prevalence of auditory and vestibular changes among individuals with SS, as well as to list the hypotheses formulated to explain such changes.

\section{RESEARCH STRATEGY}

For this analysis, a systematic literature review, without meta-analysis, was conducted on studies that investigated auditory and vestibular changes in patients with SS. By checking PubMed, LILACS, Web of Science, SciELO, and SCOPUS, articles published until December 2011 were obtained by a combination of the following keywords in the abstracts: "systemic sclerosis AND balance OR vestibular" and "systemic sclerosis AND hearing OR auditory." These keywords were selected after DeCS (Descritores em Ciências da Saúde) and MESH (Medical Subject Headings) were consulted. On the basis of articles that dealt with the studied topic, other free terms were also used.

\section{SELECTION CRITERIA}

The study included original research articles on auditory and vestibular changes in patients with SS published in Portuguese, Spanish, or English. All the literature reviews, letters, and editorials were excluded from the study. After reading their titles and abstracts, 15 articles were pre-selected. They all studied the matter of investigation and met the inclusion criteria defined for the study. Of the 15 articles, 5 were not available in the BIREME database; therefore, 10 articles were included in this study (Figure 1).

\section{DATA ANALYSIS}

For each selected article, the study design was described by using a script including location, period of publication, study design/base, and population. Afterwards, the characteristics and frequency of auditory and vestibular changes identified in individuals with SS were described. Then, the hypotheses described in the selected studies were presented to explain the physiopathology of auditory and vestibular changes in SS.

\section{RESULTS}

After consulting the electronic databases, 254 articles were found. However, only 10 were selected for this study. The most common reason for exclusion was the investigation of diagnosis, treatment, physiopathology, and other manifestations of SS that did not include auditory and vestibular changes (39\%), followed by studies that reported other pathologies (28\%), those in which the type of study did not meet the inclusion $(16 \%)$ or language criteria $(8 \%)$, and when the full text was not found $(2 \%)$. 


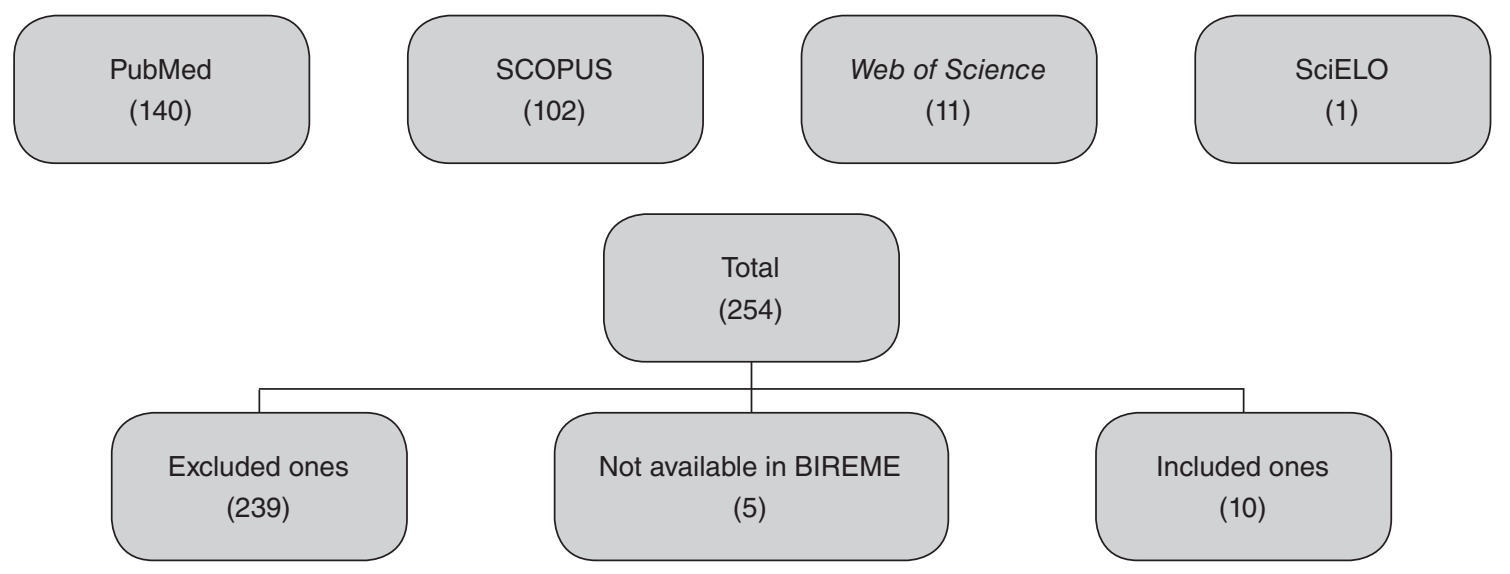

Figure 1. Database consultation and selection of articles

The earliest identified study was conducted in 1980, and 10 cases of patients diagnosed with SS who developed injury of the cranial nerve were reported ${ }^{(9)}$ (Chart 1). From 2006 onward, more publications on studies conducted in Europe, and, in Brazil, no studies analyzing auditory and vestibular compromise in SS were identified. It can be observed that in the past four decades there were only a few studies with the objective of investigating auditory and vestibular changes among individuals with SS. It is believed that because the disease is rare and its diagnosis is late, studies to investigate auditory and balance in these individuals become compromised. Besides, we should consider that the evolution, symptoms, limitations, and prognosis of the disease draw the attention of professionals who work with these patients towards restoring the functions and skills essential to maintain their lives. However, it is noteworthy that the integrity of hearing and balance enables these patients to socialize and gain autonomy, contributing to their well-being and quality of life.

The most used study design for describing auditory and vestibular changes in individuals with SS was the crosssectional design, observed in five analyses ${ }^{(10-14)}$, followed by four case reports ${ }^{(6,9,15,16)}$, and one case-control study ${ }^{(17)}$. Because cross-sectional studies reported findings of a single moment, it was difficult to determine a temporal sequence between exposure to a specific factor and the subsequent development of the disease. This type of study is not considered to be the most appropriate or indicated one to investigate hearing and balance among individuals with SS. This is because there is a possibility that at the time of evaluation, auditory and vestibular changes had not manifested. Besides, it is impossible to ensure that SS was present before the development of hearing loss or vestibular changes. Therefore, and considering the progressive aspect of SS, more follow-up studies are required to establish a temporal sequence between the disease and the onset or aggravation of auditory and vestibular changes among individuals with SS.

The largest sample was observed in the study by AmorDorado et al. ${ }^{(12)}$, which included 42 individuals with SS, and the smallest sample was observed in the study by Maciaszczyk et al. ${ }^{(13)}$, including 20 people diagnosed with SS. The reduced number of the samples is probably because of the fact that SS is a rare and progressive disease, with several incapacitating manifestations leading to death.

Amor-Dorado et al. ${ }^{(12,17)}$ and Maciaszczyk et al. ${ }^{(13)}$ had differences in the study population with regard to the form of disease (limited or diffuse); however, only in the analysis by Amor-Dorado et al. ${ }^{(12)}$ results were presented by considering the type of disease. Prevalence of changes in the vestibular system was higher for patients with diffuse SS (Charts 1 and 2). Considering that the level of systemic manifestations is directly related to the form of disease presentation (limited or diffuse), it is hypothesized that auditory and vestibular changes also have these variations, which emphasizes the importance of distinguishing the study population according to the form of disease.

Only the studies by Berrettini et al. ${ }^{(10)}$ and Amor-Dorado et al. ${ }^{(17)}$ investigated auditory and vestibular involvement in patients with SS. However, six studies aimed at assessing or reporting only auditory changes in these patients ${ }^{(6,9,11,13,15,16)}$ and only two ${ }^{(12,14)}$ investigated vestibular dysfunctions (Chart 1).

It is possible to observe that symptoms of hearing loss, tinnitus, and vertigo were more frequently reported by individuals with SS. As to the presence of changes, hearing loss was the most common finding in the studies (Chart 2). However, it is important to consider that, of the 10 analyzed studies, 6 observed only hearing changes. Of the eight studies that investigated changes, all identified hearing loss in most individuals with SS, and the prevalence in this finding ranged from 20 to $77 \%$. The type of hearing loss was bilateral sensorineural ${ }^{(6,9-11,13,16,17)}$ in most cases, corroborating the physiopathology of the systemic disease. However, $\operatorname{mixed}^{(11,15,17)}$ and unilateral ${ }^{(13,17)}$ hearing loss were also described in few cases.

The configuration and level of hearing loss were little explored in the studies. As this information is very important because it will guide the auditory rehabilitation process among these individuals, it should be included while conducting new studies. AmorDorado et al. ${ }^{(17)}$ described the flat hearing loss configuration in 13 individuals and high-frequency hearing loss in 14, accounting 
Chart 1. Characterization of the studies investigating auditory and vestibular changes in patients with systemic sclerosis

\begin{tabular}{|c|c|c|c|c|}
\hline Author & Study location & Study design & $\begin{array}{c}\text { Population/Sample } \\
\end{array}$ & Analyzed variables \\
\hline Santarelli et al..$^{(5)}$ & Italy & Case report & $\begin{array}{l}\text { Patient with SS and auditory neuropathy, } \\
\text { female, } 16 \text { years old }\end{array}$ & $\begin{array}{l}\text { SS, speech perception and } \\
\text { electrophysiology for hearing }\end{array}$ \\
\hline Teasdall et al. ${ }^{(9)}$ & USA & Case report & $\begin{array}{l}10 \text { cases of patients with SS who have injury of } \\
\text { cranial nerve }\end{array}$ & SS and cranial nerves \\
\hline Berrettini et al. ${ }^{(10)}$ & Italy & Cross-sectional & $\begin{array}{l}37 \text { patients with SS in the rheumatology unit of } \\
\text { the University of Pisa, aged between } 42 \text { and } \\
69 \text { years }\end{array}$ & $\begin{array}{l}\text { SS, auditory, and vestibular } \\
\text { changes }\end{array}$ \\
\hline $\begin{array}{l}\text { Kastanioudakis } \\
\text { et al. }{ }^{(11)}\end{array}$ & Greece & Cross-sectional & $\begin{array}{l}\text { Case group: } 30 \text { patients with SS, divided by age } \\
\text { group (A: } 18-39 \text { years old; } B: 40-54 \text { years old; } \\
\text { C: } 55-64 \text { years old D: }>64 \text { years old); } 17 \text { had } \\
\text { limited SS and } 13 \text { had diffuse SS; Comparison } \\
\text { group: } 45 \text { patients with history of HL }\end{array}$ & $\begin{array}{l}\mathrm{HL} \text {, type of SS, systemic } \\
\text { manifestations of the disease, } \\
\text { treatment with medicines and } \\
\text { immunological evaluation }\end{array}$ \\
\hline $\begin{array}{l}\text { Amor-Dorado } \\
\text { et al. }{ }^{(12)}\end{array}$ & Spain & Cross-sectional & $\begin{array}{l}\text { Case group: } 42 \text { individuals with SS ( } 35 \text { with } \\
\text { limited SS and } 7 \text { with diffuse SS), in the } \\
\text { Rheumatology Service of Hospital Xeral-Calde; } \\
\text { Comparison group: } 74 \text { individuals selected from } \\
\text { the general population of Lugo }\end{array}$ & SS and vestibular changes \\
\hline $\begin{array}{l}\text { Maciaszczyk } \\
\text { et al. }{ }^{(13)}\end{array}$ & Poland & Cross-sectional & $\begin{array}{l}\text { Case group: } 20 \text { individuals with SS ( } 13 \text { with } \\
\text { limited SS, } 6 \text { with diffuse SS, and } 1 \text { with } \\
\text { the CREST syndrome, without sclerosis); } \\
\text { Comparison group: } 26 \text { individuals }\end{array}$ & $\begin{array}{l}\text { Prevalence of auditory changes, } \\
\text { Raynaud's phenomenon, duration, } \\
\text { type, and severity of SS }\end{array}$ \\
\hline Bassyouni et al. ${ }^{(14)}$ & Egypt & Cross-sectional & $\begin{array}{l}\text { Case group: } 30 \text { female patients with SS, } \\
\text { from the Department of Rheumatology and } \\
\text { Rehabilitation at the University of Medicine } \\
\text { in Cairo; comparison group: } 29 \text { healthy } \\
\text { female volunteers }\end{array}$ & $\begin{array}{l}\text { Type and duration of SS, } \\
\text { vestibular dysfunction, and age } \\
\text { of individuals }\end{array}$ \\
\hline $\begin{array}{l}\text { Abou-Taleb and } \\
\text { Linthicum }^{(15)}\end{array}$ & USA & Case report & Female 51-year-old patient, with generalized SS & SS and $\mathrm{HL}$ \\
\hline Deroee et al. ${ }^{(16)}$ & USA & Case report & Male 65-year-old patient, diagnosed with SS & $\mathrm{SS}$ and $\mathrm{HL}$ \\
\hline $\begin{array}{l}\text { Amor-Dorado } \\
\text { et al. }{ }^{(17)}\end{array}$ & Spain & Case-control & $\begin{array}{l}\text { Case group: } 35 \text { patients with limited SS, from } \\
\text { the Rheumatology Service of Hospital Xeral- } \\
\text { Calde; control group: } 59 \text { individuals selected } \\
\text { from the general population of Lugo }\end{array}$ & $\begin{array}{l}\text { SS, complaint of HL, vertigo, } \\
\text { dizziness, lack of balance and } \\
\text { audiological, vestibular, and } \\
\text { oculographic evaluation }\end{array}$ \\
\hline
\end{tabular}

Caption: SS = systemic sclerosis; HL = hearing loss; CREST = calcinosis, Raynaud's phenomenon, esophageal dysmotility, sclerodactyly, and telangiectasia

for 27 patients with sensorineural hearing loss (SNHL). Deroee et al. ${ }^{(16)}$ observed high-frequency hearing loss in one of the ears and severe loss in another. In a study by Maciaszczyk et al. ${ }^{(13)}$, most individuals in the case group presented moderate hearing loss (Chart 2).

Regarding vestibular changes, prevalence ranged from 11 to $63 \%$, and the most common findings were changes in caloric testing, positional nystagmus, abnormal oculocephalic reflex, changes in clinical tests of sensory integration, and benign paroxysmal positional vertigo ${ }^{(6,10,12,17)}$. The prevalence of vestibular changes deserves the attention of professionals assist these patients, because these changes lead to balance changes, which, together with locomotive changes (characteristics of the disease), can be incapacitating and compromise the autonomy of patients with SS.

The analyzed studies have tried to elucidate the frequency and magnitude of auditory and vestibular changes by evaluating the peripheral and central systems. The basic audiological evaluation (tone audiometry, vocal audiometry, and acoustic immittance) was the most used evaluation method to identify these changes in individuals with $\mathrm{SS}^{(6,10,11,13,15,17)}$. However, the brainstem auditory-evoked potentials (BAEP) and vestibular evaluation were also used for diagnostic investigation ${ }^{(6,10,13,17)}$. The highest prevalence of peripheral auditory changes can be the reflex of the assessment instrument used in the studies. Therefore, it is important that new studies be conducted with the objective of investigating the presence of auditory changes in the central system, as well as changes related to balance in individuals with $\mathrm{SS}$.

Regarding the biological plausibility of auditory changes in individuals with SS, only one study suggested the possible mechanisms. According to Deroee et al. ${ }^{(16)}$, hearing damage in patients with SS first affects high-frequency hearing, and patients may not be aware of their hearing loss due to the severity of other manifestations of the disease. These authors suggest that the inflammation of small vessels in the cochlear nerve and the reduced blood flow to the cochlea may be the beginning of the inner ear pathogenesis in autoimmune diseases. 
Chart 2. Symptoms and auditory and vestibular findings in systemic sclerosis

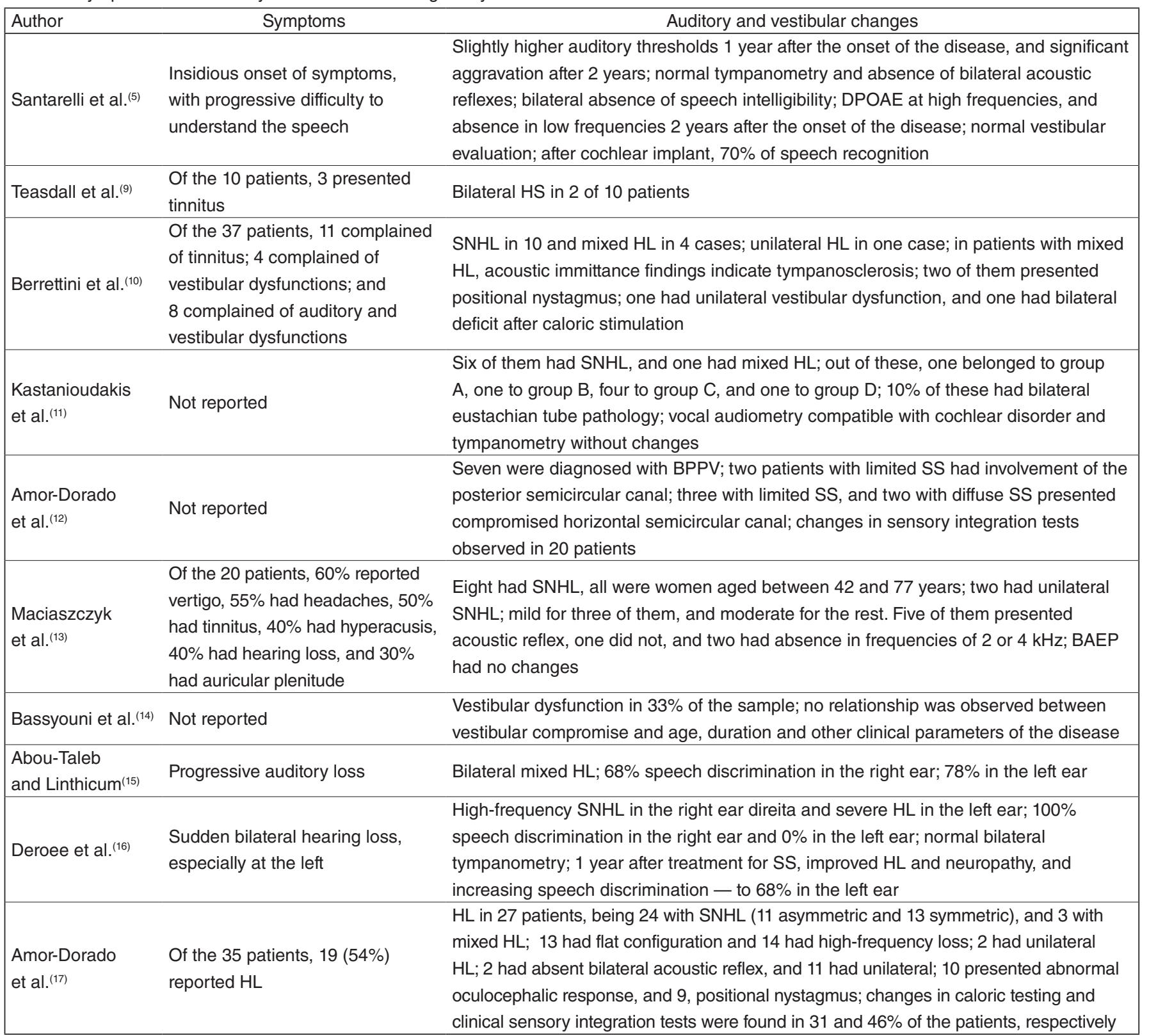

Caption: $\mathrm{HL}$ = hearing loss; SNHL = sensorineural hearing loss; DPOAE = distortion product otoacoustic emissions; BPPV: benign paroxysmal positional vertigo; SS: systemic sclerosis; BAEP = brainstem auditory-evoked potentials

The inner ear compromise, especially the cochlea, may be a consequence of a vascular change, once this change is the base of SS physiopathology. The irregular structure of blood vessels associated with the reduced density of capillaries may result in decreased blood flow and, consequently, hypoxia ${ }^{(16)}$. The cochlea is a highly sensitive organ to blood changes, and the hypoxia resulting from vascular changes of the disease may lead to the death of hair cells ${ }^{(18)}$. Clinically, these changes are expressed by SNHL, which corroborates the findings of the studies that indicate lower prevalence of this type of hearing loss.

Literature also describes mixed hearing loss in these individuals; however, no biological mechanisms that could explain this implication on SS have been reported. However, studies show the occurrence of conductive hearing loss in other autoimmune diseases such as recidivant polychondritis, thus attributing this change to the expansion of the inflammatory process to the middle ear and auditory tube ${ }^{(19)}$.

In one of the reviewed articles, the authors ${ }^{(1)}$ identified the presence of eustachian tube pathology in 3 of the 30 evaluated patients. This change may explain the presence of the conductive component in the hearing loss of patients with ES. As the physiopathology of SS involves not only vascular injuries but also tissue and joint injuries, there is also a possibility of middle ear involvement, because of the mechanical impairment of structures composing the tympanic-ossicle system, leading to changes in sound conduction. 
The physiopathology of vestibular changes was not discussed in any of the articles included in this study. However, it is important to investigate how these changes occur, to intervene early, when possible, thus contributing to improvement in the quality of life of individuals who present with dysfunctions in this system, once they can empower locomotion limitations in people with SS.

Auditory and vestibular changes, when added to manifestations resulting from the disease, may lead to even significant damage when it comes to the socialization of these individuals. Therefore, knowing about these changes can indicate the need to include the evaluation of peripheral and central auditory system in the diagnosis protocol, as well as the follow-up of these people, to detect such changes and adopt rehabilitation procedures or medicines that can be applied early and be effective.

\section{CONCLUSION}

The results of the analyzed studies indicate auditory and vestibular compromise in patients with SS, and it is possible to observer higher prevalence of bilateral SNHL. The configuration and level of hearing loss were considered in a few studies, and results were inconsistent.

Auditory symptoms may precede the manifestations of the autoimmune disease; therefore, they can be useful in the early diagnosis, when SS is suspected. The early diagnosis and comprehension of the physiopathology of auditory and vestibular changes caused by SS are essential for taking necessary measures for their prevention and rehabilitation.

New investigations should be conducted with the objective of clarifying the relation between the configuration and level of hearing loss with the severity and form of disease presentation (limited or diffuse), contributing to the knowledge of whether or not the progression and form of disease affect the level of auditory and vestibular manifestations.

The analysis of the selected articles for this review indicates the importance of standardizing the measurement of study outcomes, so that it is possible to perform future metaanalyses that will contribute to practices based on evidence. Besides, the need for studies investigating the physiopathology of auditory and vestibular changes among individuals with SS is worth mentioning.

*MBR was in charge of theme conception and design, data collection, tabulation and analysis, writing the article, and approving the final version. APC contributed to the study methodology, analysis, and general orientation of the stages of manuscript elaboration, as well as approval of the final version.

\section{REFERENCES}

1. Azevedo ABC, Sampaio-Barros PD, Torres RM, Moreira C. Avaliação da prevalência de hipertensão pulmonar na esclerose sistêmica. Rev Bras Reumatol. 2004;44(1):31-9.

2. Vilas AP, Veiga MV, Abecasis P. Esclerose sistêmica - perspectivas actuais. Med Interna. 2002;9(2):111-20.

3. Godoi ETAM, Barbosa AD, Godoi JTAM, Ramos MAM, Godoi JTAM, Marques SRB, et al. Envolvimento macrovascular e esclerose sistêmica. J Vasc Bras. 2009;8(1):65-76.

4. Borges CTL. Esclerose sistêmica. In: Yoshinari NH, Bonfá ESDO, organizadores. Reumatologia para o clínico. São Paulo: Roca; 2000. p. 49-58.

5. Santarelli R, Monte PSED, Arslan EGE. Auditory neuropathy in systemic sclerosis: a speech perception and evoked potential study before and after cochlear implantation. Eur Arch Otorhinolaryngol. 2006;263:809-15.

6. Gilliland BC. Esclerose sistêmica (esclerodermia) e distúrbios relacionados. In: Kasper DL, editor. Tratado de medicina interna. Rio de Janeiro: McGraw-Hill; 2006. p. 2076-87.

7. Skare TL. Reumatologia: princípios e práticas. Rio de Janeiro: Guanabara Koogan; 2007. p. 125-34.

8. Sandqvist G, Hesselstrand R, Scheja A, Hakansson C. Managing work life with systemic sclerosis. Rheumatol. 2012;51:319-23.

9. Teasdall RD, Frayaha RA, Schulman LE. Cranial nerve involvement in systemic sclerosis (scleroderma): a report of 10 cases. Medicine (Baltimore). 1980;59(2):149-59.

10. Berrettini S, Ferri C, Pitaro N, Bruschini P, Latorraca A, SellariFranceschini S, et al. Audiovestibular involvement in systemic sclerosis. ORL. 1994;56:195-8.

11. Kastanioudakis I, Ziavra N, Politi EN, Exarchakos G, Drosos AA, Skevas A. Hearing loss in progressive systemic sclerosis patients: a comparative study. Otolaryngol Head Neck Surg. 2001;124(5):522-5.

12. Amor-Dorado JC, Barreira-Fernandez MP, Arias-Nuñez MC, GomezAcebo A, Llorca J, Gonzalez-Gay MA. Benign paroxysmal positional vertigo and clinical test of sensory interaction and balance in systemic sclerosis. Otol Neurotol. 2008;29(8):1155-61.

13. Maciaszczyk K, Waszczykowska E, Pajor A, Bartkowiak-Dziankowska B, Durko T. Hearing organ disorders in patients with systemic sclerosis. Rheumatol Int. 2011;31(11):1423-8.

14. Bassyouni IH, Emad Y, Rafaat HA, Dabbous AO. Relationship between nailfold capillary abnormalities and vestibular dysfunction in systemic sclerosis. Joint Bone Spine. 2011;78(3):266-9.

15. Abou-Taleb A, Linthicum FH Jr. Scleroderma and hearing loss: (histopathology of a case). J Laryngol Otol. 1987;101(7):656-62.

16. Deroee AF, Huang TC, Morita N, Hojjati M. Sudden hearing loss as the presenting symptom of systemic sclerosis. Otol Neurotol. 2009;30(3):277-9.

17. Amor-Dorado JC, Arias-Nuñez MC, Miranda-Filloy JA, GonzalezJuanatey C, Llorca J, Gonzalez-Gay MA. Audiovestibular manifestations in patients with limited systemic sclerosis and centromere protein-B (CENP-B) antibodies. Medicine (Baltimore). 2008;87(3):131-41.

18. Lazarini PR, Camargo ACK. Surdez súbita idiopática: aspectos etiológicos e fisiopatogênicos. Rev Bras Otorrinolaringol. 2006;72(4):554-61.

19. Pereira DB, Amaral JLA, Szajubok JCM, Lima SMAL, Chahade AH Manifestações otorrinolaringológicas nas doenças reumáticas autoimunes. Rev Bras Reumatol. 2006;46(2):118-25. 